\title{
Costimulating aberrant $T$ cell responses by B7-H1 autoantibodies in rheumatoid arthritis
}

\author{
Haidong Dong, ${ }^{1}$ Scott E. Strome, ${ }^{2}$ Eric L. Matteson, ${ }^{3}$ Kevin G. Moder, ${ }^{3}$ Dallas B. Flies, ${ }^{1}$ \\ Gefeng Zhu, ${ }^{1}$ Hideto Tamura, ${ }^{1}$ Colin L.W. Driscoll, ${ }^{2}$ and Lieping Chen ${ }^{1}$ \\ ${ }^{1}$ Department of Immunology, \\ ${ }^{2}$ Department of Otorhinolaryngology, and \\ ${ }^{3}$ Division of Rheumatology, Department of Internal Medicine, Mayo Medical School and Graduate School, Mayo Clinic, \\ Rochester, Minnesota, USA
}

\begin{abstract}
A pathogenic hallmark of rheumatoid arthritis (RA) is persistent activation of self-reactive $C D 4^{+} \mathrm{T}$ cells. The cause of this aberrant activity remains elusive. We report here detection of autoantibodies against B7-H1, a recently described member of the B7 family, in $29 \%$ of patients with RA versus $4 \%$ of healthy donors. High-level expression of cell surface $\mathrm{B} 7-\mathrm{H} 1$ are found on activated human $\mathrm{CD}^{+}, \mathrm{CD}^{+}$, and $\mathrm{CD} 45 \mathrm{RO}^{+} \mathrm{T}$ cells. Immobilized autoantibodies to $\mathrm{B} 7-\mathrm{H} 1$ are capable of costimulating the proliferation of $\mathrm{CD}^{+} \mathrm{T}$ cells in vitro, and the presence of these autoantibodies correlates with active disease status. Using immobilized B7-H1 mAb's and programmed death 1Ig, we demonstrate that engagement of B7-H1 on CD4 $4^{+} \mathrm{T}$ cells costimulates proliferation and secretion of IL-10, and subsequently leads to programmed cell death, accompanied with upregulated expression of TNF-related apoptosis-inducing ligand and activation of caspase-3. Taken together with our previous findings, these data indicate a bidirectional signaling role of $\mathrm{B} 7-\mathrm{H} 1$ in $\mathrm{T}$ cell costimulation and apoptosis and implicate $\mathrm{B} 7-\mathrm{H} 1$ autoantibodies as contributing to the progression of RA by inducing aberrant $\mathrm{T}$ cell responses.
\end{abstract}

J. Clin. Invest. 111:363-370 (2003). doi:10.1172/JCI200316015.

\section{Introduction}

Leukocyte infiltration into the synovium of rheumatoid arthritis (RA) patients results in extensive joint inflammation, characteristic of disease pathogenesis (1). The majority of infiltrating cells are $\mathrm{CD} 4^{+} \mathrm{T}$ cells, which express activation/memory markers including CD45R, CD44, HLA-DR, and VLA-1 $(2,3)$, suggesting a persistent state of hyperreactivity. The cause of this aberrant $T$ cell activation has been attributed to the presentation of arthritogenic antigens by HLA-DR (4), existence of superantigen, and homeostatic proliferation $(5,6)$.

One alternative explanation for persistent $T$ cell activation in systemic autoimmune diseases such as RA may come from the study of $\mathrm{T}$ cell costimulation. It is well accepted that, in addition to the engagement of the $\mathrm{T}$ cell receptor (TCR) with antigen, costimulation is required for optimal activation of $\mathrm{T}$ cells. The bestcharacterized costimulatory pathways are interactions

Received for publication May 28, 2002, and accepted in revised form December 4, 2002.

Address correspondence to: Lieping Chen, Department of Immunology, Mayo Clinic, 200 First Street SW, Rochester, Minnesota 55905, USA. Phone: (507) 538-0013;

Fax: (507) 284-1637; E-mail: chen.lieping@mayo.edu.

Haidong Dong and Scott E. Strome contributed equally to this work.

Conflict of interest: The authors have declared that no conflict of interest exists.

Nonstandard abbreviations used: rheumatoid arthritis (RA); $\mathrm{T}$ cell receptor (TCR); programmed death 1 (PD-1);

phycoerythrin (PE); TNF-related apoptosis-inducing ligand (TRAIL); annexin V (AV); propidium iodide (PI); phytohemagglutinin (PHA). of CD28 and CTLA-4 on the T cell with B7-1 (CD80) and B7-2 (CD86) on APCs $(7,8)$. In addition to the natural receptor-ligand interaction, receptor-specific agonistic $\mathrm{Ab}$ can also deliver costimulatory signals. In fact, agonistic $\mathrm{Ab}$ often results in much stronger signaling than that from natural ligand, possibly due to their high affinity and/or immobilization on cells expressing $\mathrm{Fc}$ receptor in vivo (9-12). Agonistic Ab ligation of costimulatory molecules may be particularly relevant in autoimmune diseases in which autoantibodies are commonly detected. In fact, autoantibodies against CTLA- 4 recently have been identified in the serum of patients with RA and Behcet disease, although the functional significance of these autoantibodies remains unknown (13).

B7-H1 is a third member of the B7 family that costimulates primary $T$ cells through a putative receptor (14), but may inhibit proliferation of preactivated $\mathrm{T}$ cells (15). In vitro stimulation of primary human $T$ cells with B7-H1Ig or B7-H1 transfectants promotes both IL-10 secretion and proliferation, but without the accompanying increased production of IL-2. A putative counter-receptor, PD-1 (programmed death 1), were reported recently (15). Recently, we reported that many human malignancies express B7-H1 and ligation of tumor-associated B7-H1 to a non-PD-1 receptor promotes apoptosis of activated $T$ cells (16), suggesting the expression of B7-H1 may represent a new mechanism for tumor evasion of immunity.

In addition to signals through binding receptor on $\mathrm{T}$ cells, select members of the B7 family could also have receptor functions, mediated through a process termed 
reverse signaling. Specifically, B7-2 demonstrates reverse signaling on $\mathrm{B}$ cells, resulting in differentiation and class switching (17). B7-H1 is expressed on activated human and mouse $T$ cells $(14,18)$. This pattern of B7-H1 expression led us to postulate that engagement of B7-H1 might play a direct role in the regulation of the human $T$ cell response in autoimmune diseases, such as RA, resulting in a persistent state of $\mathrm{T}$ cell activation in affected individuals.

\section{Methods}

Patients and healthy donors. Sera samples were obtained from 63 patients with diagnosed RA autoimmune disease and 54 sex- and age-matched healthy donors under the approval of the Internal Review Board of the Mayo Clinic. Diagnosis of RA was defined according to the classification criteria of the American College of Rheumatology. Sera or plasma samples were collected from 63 RA patients ( 53 women and 10 men, mean age, 58 years; age range, $17-80$ years) and 54 healthy donors ( 42 women and 12 men, mean age, 52; age range 20-69). Human IgG was purified by ImmunoPure $(\mathrm{G})$ IgG purification kits (Piece Chemical Co., Rockford, Illinois, USA).

ELISA. Purified human B7-H1Ig (mouse IgG2a Fc) (14) or control mIgG2a at $2 \mu \mathrm{g} / \mathrm{ml}$ in PBS was coated overnight on an ELISA plate at $4^{\circ} \mathrm{C}$ followed by blocking with PBS containing 10\% FBS. Sera from healthy donors or RA patients were diluted in PBS at 1:1,000 in triplicate before adding to the plates. After reaction, the wells were washed six times in PBS with $0.1 \%$ Tween-20. Bound $\mathrm{Ab}$ 's were detected by horseradish peroxidase-conjugated goat anti-human IgG Ab (BioSource International Camarillo, California, USA) at a 1:2,000 dilution for 1.5 hour at room temperature, then reacted with tetramethylbenzidine, and measured using a multimicroplate reader at $450 \mathrm{~nm}$. Nonspecific binding of sera to plates coated with control Ig (mouse IgG2a) was subtracted from each sample.

Generation of $m A$ s s to B7-H1. BALB/c mice were immunized with purified human B7-H1Ig mixed with complete Freud's adjuvant (Sigma-Aldrich, St. Louis, Missouri, USA) and boosted three times with B7-H1Ig in incomplete Freud's adjuvant. Sera from the mice were collected, and their specific binding to B7-H1 was determined by ELISA and by FACS analysis on B7-H1/293 cells (14). The spleen cells from mice with highest titer of antisera were fused with SP2/0 myeloma cells to produce hybridoma cells. After several rounds of selection by ELISA and by FACS, two clones, $2 \mathrm{H} 1$ and $5 \mathrm{H} 1$, which consistently stain B7-H1/293 cells, were selected. The isotype of $2 \mathrm{H} 1$ or $5 \mathrm{H} 1$ is IgG1. The culture supernatant of hybridomas was concentrated and purified by a protein G-Sepharose column (Pierce Chemical Co.) and dialyzed in LPS-free PBS. In some experiments, polymyxin $\mathrm{B}$ was incorporated in the assays of cell proliferation and cytokine secretion to neutralize residual endotoxin.

$T$ cell activation and FACS analysis. Freshly isolated human PBMCs $\left(10^{7}\right.$ cells $\left./ \mathrm{ml}\right)$ were stimulated with 5 $\mu \mathrm{g} / \mathrm{ml}$ of phytohemagglutinin (PHA) (Sigma-Aldrich). Cells were harvested and analyzed at 0, 24, and 48 hours upon treatment. For direct immunofluorescence staining, $\mathrm{T}$ cells were incubated at $4^{\circ} \mathrm{C}$ with $1 \mu \mathrm{g}$ of FITC- or phycoerythrin-conjugated (PE-conjugated) $\mathrm{mAb}$ for 30 minutes and analyzed by FACScan flow cytometry (Becton Dickinson Immunocytometry Systems, Mountain View, California, USA) with Cell Quest software (Becton Dickinson Immunocytometry Systems), as described previously (14). The mAb specific for CD4 (RPA-T4), CD8 (RPA-T8), and CD45RO (UCHL1) were purchased from BDPharMingen (San Diego, California, USA), and rabbit anti-human TNF-related apoptosis-inducing ligand (TRAIL) polyclonal Ab's were purchased from Alexis Biochemical Corp. (San Diego, California, USA). For indirect immunofluorescence staining, cells were first incubated with B7- $\mathrm{H} 1 \mathrm{mAb}(3 \mu \mathrm{g} / \mathrm{sample})$ at $4{ }^{\circ} \mathrm{C}$ for 30 minutes. The cells were washed and further incubated with FITC-conjugated (BioSource International) or PE-conjugated (Southern Biotechnology Associates, Birmingham, Alabama, USA) goat anti-mouse $\operatorname{IgG~F}\left(\mathrm{ab}^{\prime}\right)_{2}$ for 30 minutes at $4^{\circ} \mathrm{C}$. The mouse IgG-1 (Sigma-Aldrich) was used as control Ig. In some experiments, cells were treated with human Ig before incubation with FITC- or PE-conjugated mAbs to block interference of $\mathrm{Fc}$ receptors.

Costimulation of $T$ cell responses. Purified human $\mathrm{CD}^{+}$ $\mathrm{T}$ cells at $2 \times 10^{5}$ cells/well in triplicate were cultured in 96-well flat-bottomed plates that were precoated overnight with anti-CD3 mAb (HIT3a; BD-PharMingen) in the presence of B7-H1 mAbs, PD-1Ig, or control $\mathrm{Ab}$ (mouse IgG1). To detect cytokines, supernatants were harvested at 24,48 , and 72 hours of the cultures, and the concentrations of IL-10 were determined by sandwich ELISA methods (BD-PharMingen), according to manufacturer's instructions. Anti-CD28 mAb (CD28.2; BD-PharMingen) was included as positive control. For blocking the effects of B7-H1 mAb, soluble B7-H1Ig or control Ig (mIgG2a) was precultured with coated $\mathrm{B} 7-\mathrm{H} 1 \mathrm{mAb}$ for 30 minutes before the addition of $\mathrm{CD}^{+} \mathrm{T}$ cells. T cell proliferation was determined by the addition of $1.0 \mu \mathrm{Ci}{ }^{3} \mathrm{H}-\mathrm{TdR}$ for the final 16 hours of culture. The incorporation of ${ }^{3} \mathrm{H}-\mathrm{TdR}$ was counted by a MicroBeta TriLux liquid scintillation counter (Wallac, Turku, Finland).

Induction and analysis of apoptosis. Purified human $\mathrm{CD}^{+} \mathrm{T}$ cells $\left(4 \times 10^{5} / \mathrm{ml}\right)$ were cultured with $\mathrm{B} 7-\mathrm{H} 1$ $\mathrm{mAb}$ 's or a control mAb at $10 \mu \mathrm{g} / \mathrm{ml}$ in the presence of immobilized anti-CD3 mAb $(500 \mathrm{ng} / \mathrm{ml})$. At each time point, aliquots $\left(10^{5}\right)$ of the cells were stained by FITCconjugated annexin V (AV) (BD PharMingen) at 5 $\mu \mathrm{l} /$ test and propidium iodide (PI) (Sigma-Aldrich) at 5 $\mu \mathrm{g} / \mathrm{ml}$ for 1 hour. The samples were analyzed by FACS. For blocking the effect of apoptosis, the neutralizing $\mathrm{mAb}$ to IL-10 (R\&D Systems Inc., Minneapolis, Minnesota, USA), IL-2 (MQ-17H12; BD-PharMingen), or to Fas ligand (NOK-1; BD-PharMingen) were added at $10 \mu \mathrm{g} / \mathrm{ml}$ at the beginning of culture. 
Detection of apoptosis-related genes. Total RNA was prepared using TRI Reagent (Sigma-Aldrich) from $5 \times 10^{6}$ $\mathrm{T}$ cells, which were stimulated by anti-CD3/B7-H1 mAb or anti-CD3/control Ab for 24, 48, 72 hours. RNA (10 $\mu \mathrm{g})$ was used as a template for ${ }^{32} \mathrm{P}$ cDNA probe synthesis. Human apoptosis1 GEArray (SuperArray Inc. Bethesda, Maryland, USA) is composed of 23 apoptosisrelated genes and two housekeeping genes, actin and GAPDH. Analysis of gene expression was carried out by side-by-side hybridization with the cDNA probe according to the user manual. A STORM PhosphoImager system (Molecular Dynamics, Sunnyvale, California, USA) was used to directly quantify the intensity of the signals. The relative abundance of a particular transcript was estimated by comparing its signal intensity to the signal derived from $\beta$-actin or GAPDH. The results represent a fold increase of signals from $T$ cells that were stimulated with $\mathrm{B} 7-\mathrm{H} 1 \mathrm{mAb}$ versus control $\mathrm{Ab}$.

Detection of active caspase-3. The CaspaTagTM Caspas3 (DEVD) Activity kit (Intergen Co., Purchase, New York, USA) was used to detect the activated form of caspase- 3 in $\mathrm{CD}^{+} \mathrm{T}$ cells. The kit detects active caspases in living cells by using a carboxyfluorescein-labeled caspase inhibitor (FAM-DEVD-FMK). The inhibitor irreversibly binds to active caspases, and the caspasepositive cells are detected by flow cytometry (see the manufacturer's manual). Briefly, $300 \mu \mathrm{l}$ of $10^{6}$ cells $/ \mathrm{ml}$ was transferred to a fresh tube and incubated with 10 $\mu \mathrm{l}$ of FAM-DEVD-FMK solution diluted 30 times for 1 hour at $37^{\circ} \mathrm{C}$ under $5 \% \mathrm{CO}_{2}$ in the dark. After incuba-
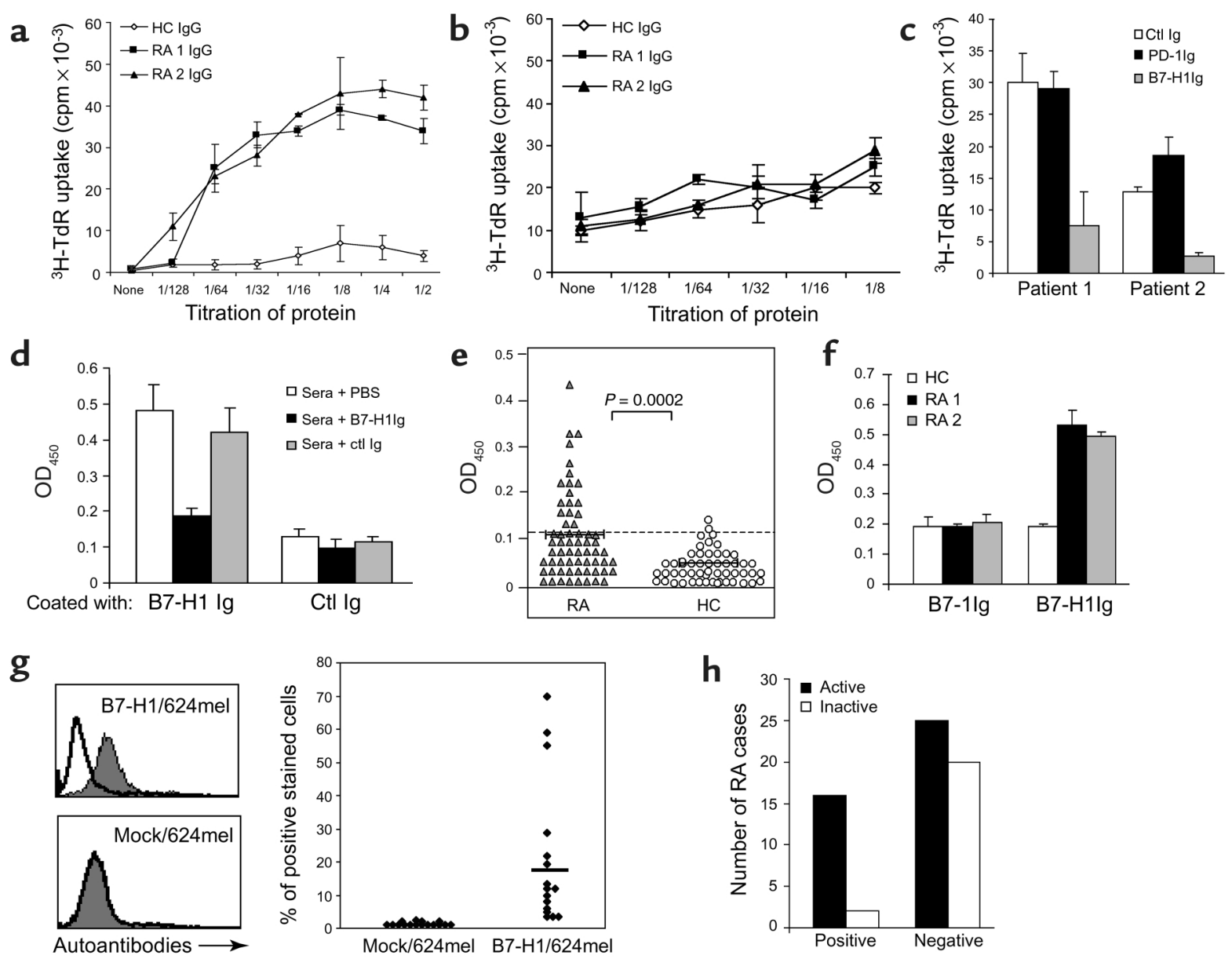

\section{Figure 1}

Detection, costimulatory function, and disease association of B7- $\mathrm{H} 1$ autoantibodies in RA patients. CD4 ${ }^{+} \mathrm{T}$ cells were cultured with immobilized (a) or soluble (b) sera $\operatorname{lgG}$ at the initiated dose of $20 \mu \mathrm{g} / \mathrm{ml}$ in the presence of suboptimal anti-CD3 mAb. The titers of RA 1 and RA 2 patients are 0.32 and $0.25\left(\mathrm{OD}_{450}\right)$, respectively. (c) For blockade, the control (ctl) lg, PD-1/g, or B7- $\mathrm{H} 1 \mathrm{lg}$ at $3 \mu \mathrm{g} / \mathrm{ml}$ were added before the addition of $\mathrm{CD} 4^{+} \mathrm{T}$ cells. The growth of T cells was detected after 72 hours of culture. (d) To examine specificity of RA sera binding to B7- $\mathrm{H} 1$, diluted sera were preincubated with PBS, $2 \mu \mathrm{g} / \mathrm{ml}$ of soluble B7-H1/g or control $\mathrm{lg}$ (m/gG2a). (e) Diluted sera of 63 patients with $\mathrm{RA}$ and 54 healthy donors were tested for binding to B7-H1lg by ELISA. Samples with $\mathrm{OD}_{450}$ values greater than 0.123 were considered positive. $P$ value for differences between cohorts is shown $(t$ test). (f) The sera at 1:1,000 dilution were examined for binding to B7-1lg-coated vs. B7-H1lg-coated ELISA plates. (g) Mock/624mel or B7-H1/624mel cells were stained with diluted (1:5) sera from 16 ELISA-positive RA patients. The inset bar shows the average percentage of positive staining. A typical histogram of FACS assay is shown on the left. (h) Sixtythree RA patients were sorted according to the active status of their disease, and the presence of B7-H1 autoantibodies. Statistical analysis of the correlation was performed as $P=0.0179$ in a Fisher exact test. 
a
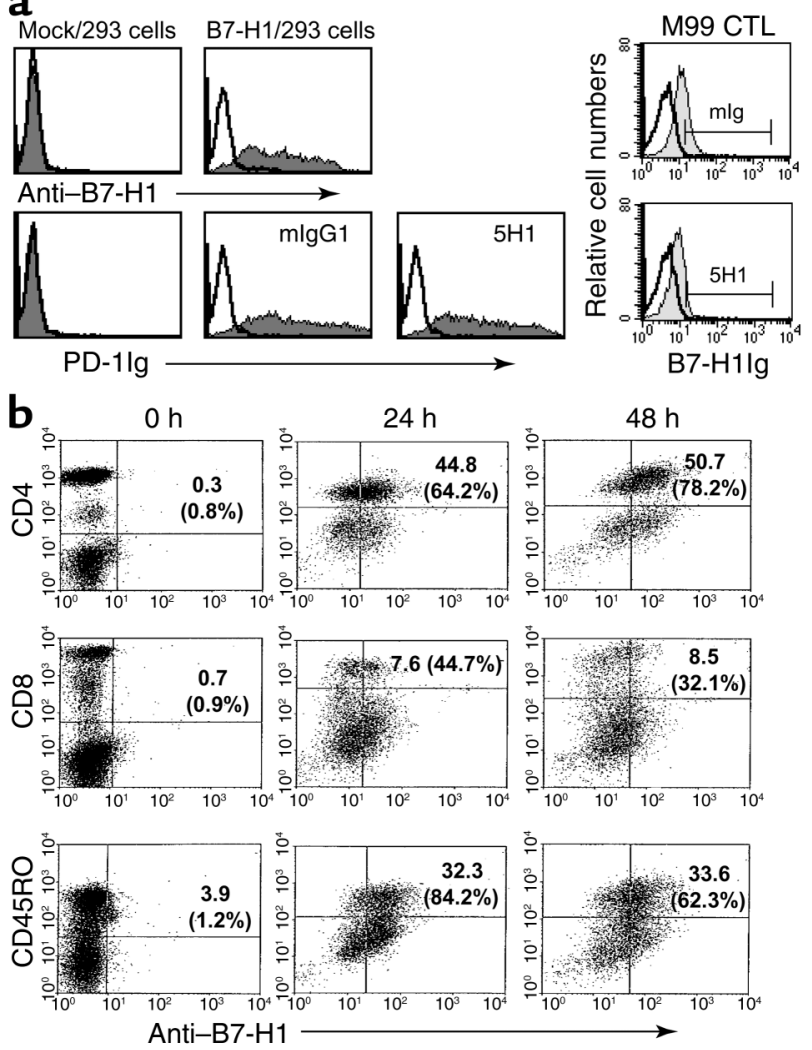

Anti-B7-H1

tion, the cells were washed twice with $2 \mathrm{ml}$ of $1 \times$ wash buffer and then were resuspended in $400 \mu \mathrm{l}$ of $1 \times$ wash buffer before analysis with FACS.

\section{Results}

Costimulatory B7-H1 autoantibodies in RA serum. In an attempt to evaluate the potential role of autoantibodies in prolonged activation of $\mathrm{T}$ cells in RA, purified IgG from the sera of RA patients were evaluated for their ability to regulate the proliferation of $\mathrm{T}$ cells in vitro. In the presence of suboptimal doses $(30-50 \mathrm{ng} / \mathrm{ml})$ of anti-CD3 $\mathrm{mAb}$ to mimic TCR signaling, purified IgG from the sera of two RA patients, but not control IgG, significantly enhanced the proliferation of purified CD $4^{+} \mathrm{T}$ cells in vitro in a dose-dependent fashion (Figure 1a). In the absence of anti-CD3 mAb, purified IgG from RA patients had no effect (data not shown). The soluble form of these autoantibodies did not have any activity in the same assay (Figure 1b). The costimulatory activity of the autoantibodies was completely blocked by inclusion of soluble B7-H1Ig fusion protein containing human B7-H1 extracellular portion and mouse IgG2a Fc (14), but not by PD-1Ig or control IgG (mouse IgG2a) (Figure 1c). Our results thus suggest that the costimulation activity for $\mathrm{CD}^{+} \mathrm{T}$ cell was mediated by autoantibodies against B7-H1 in the sera of RA, rather than by the soluble form of B7-H1 per se or autoantibodies to PD-1.

To directly demonstrate the existence of autoantibodies against B7-H1 in the sera of RA patients, sera from 63 patients with RA were examined by a specific sandwich

\section{Figure 2}

Preferential expression of B7-H1 mAb on activated CD4 ${ }^{+} \mathrm{T}$ cells. (a) On the left, 293 cells were transfected with mock (pcDNA3 vector) or human B7-H1 plasmid (pcDNA3-B7-H1cDNA) for 48 hours. $\mathrm{B} 7-\mathrm{H} 1 / 293$ cells were pretreated with $20 \mu \mathrm{g}$ of control Ig (mlgG1) or $5 \mathrm{H} 1$ before staining with PD-1Ig $(5 \mu \mathrm{g})$. On the right, activated M99 CTL cells were pretreated with $10 \mu \mathrm{g}$ of mlgG 1 or $5 \mathrm{H} 1$ before staining with $\mathrm{B} 7-\mathrm{H} 1 \mathrm{Ig}(10 \mu \mathrm{g})$. B7-H1 mAb, PD-1Ig, or B7-H1Ig were used to stain the transfected 293 cells and activated M99 CTL cells. Representative fluorescence histograms of isotype control reagents (open lines) and $\mathrm{B} 7-\mathrm{H} 1 \mathrm{mAb}$ or fusion proteins (filled lines) are shown. (b) Induction of B7-H1 expression on human $\mathrm{T}$ cell subsets. Human PBMCs were activated with PHA for indicated times and subjected to FACS analysis with $\mathrm{B} 7-\mathrm{H} 1 \mathrm{mAb}$ and $\mathrm{mAb}$ to $\mathrm{CD} 4, \mathrm{CD} 8$, or CD45RO. The numbers indicate the percentage of B7-H1 and CD4, CD8, or CD45RO double-positive cells in total populations, and the percentage in parentheses indicates the percentage of $\mathrm{B} 7-\mathrm{H} 1-$ positive cells in each $\mathrm{CD}^{+}, \mathrm{CD}^{+}$, or $\mathrm{CD} 45 \mathrm{RO}^{+}$subsets.

ELISA using plates coated with purified B7-H1Ig. Autoantibodies binding to B7-H1 were detected by antihuman IgG mAb. Our ELISA is highly specific for human B7-H1 because binding of patients' sera could be selectively blocked by preincubation of sera with soluble B7-H1Ig, but not control mIgG2a (Figure 1d). We used $0.123 \mathrm{OD}_{450}$ as a cut-off based on the mean $(0.057)+2$ SD (0.033) of the values with sera from 54 healthy donors at 1:1,000 dilutions. As shown in Figure 1e, sera from 18 of 63 sera from patients with RA (29\%) had elevated autoantibodies to B7-H1, while only $4 \%$ of 54 healthy donors were marginally positive for the presence of autoantibodies to B7-H1 $(P=0.0002)$. Similar to the findings of Matsui et al. (13), we did not detect any autoantibodies to B7-1, even in the sera that were positive for B7-H1 Ab's (Figure 1f). The presence of B7-H1 autoantibodies was also tested by binding of 624 melanoma line $(624 \mathrm{mel})$ that was transfected to express human B7-H1 (B7-H1/624mel) (16). A significant portion of sera from 16 patients, which were positive in ELISA assay, also stained for B7-H1/624mel but not Mock/624mel. The specificity of the binding was also confirmed by complete blockade with B7-H1Ig, which was preincubated with the diluted sera (data not shown). In addition, all the samples that were negative in ELISA for the presence of autoantibodies to B7-H1 did not bind B7-H1/624mel (data not shown). Our results indicate that a significant population of patients suffering from RA has elevated autoantibodies to B7-H1.

Correlation of B7-H1 autoantibodies with RA activity. As a preliminary functional determinant, we examined the possible relationship between the presence of B7-H1 autoantibodies and disease activity. Active disease was defined as the presence of at least nine tender joints, six swollen joints, and one or both of the following: 1 hour of morning stiffness or elevated Westergren sedimentation rate (19). We found a significant correlation between active disease and the presence of autoantibodies in 63 patients with RA. Eighty-nine percent of RA patients in the B7-H1 autoantibody-positive group had active disease, while only $56 \%$ of RA patients in 
B7-H1 autoantibody-negative group demonstrated disease activity $(P=0.017)$ (Figure $1 \mathrm{~h})$. These results suggest that autoantibodies to B7-H1 may be involved in disease progression by a direct effect on $\mathrm{T}$ cells.

Reverse costimulation of $\mathrm{CD}^{+} \mathrm{T}$ cells by B7-H1 $\mathrm{mAb}$. Autoantibodies from sera are polyvalent with multiple different specificities, limiting the potential for functional analysis. To facilitate further study of the effect of autoantibodies to B7-H1 on $\mathrm{T}$ cell response, we generated hybridomas that secrete $\mathrm{mAb}$ against human B7-H1. We identified two mAbs, $2 \mathrm{H} 1$ and $5 \mathrm{H} 1$, which specifically bound to B7-H1 on 293 cells transfected with human B7-H1 plasmid (B7-H1/293), but not mocktransfected 293 cells (Mock/293) by FACS analysis (Figure $2 \mathrm{a}$ ). In these and later studies, $5 \mathrm{H} 1$ and $2 \mathrm{H} 1$ showed identical features and were used interchangeably.

To determine whether or not our mAb can block interaction between $\mathrm{B} 7-\mathrm{H} 1$ and $\mathrm{PD}-1$, we examine the ability of $5 \mathrm{H} 1 \mathrm{mAb}$ to block the binding of PD-1Ig to B7-H1/293 cells. As shown in Figure 2a, PD-1Ig bound B7-H1/293 cells but not mock/293 cells. Inclusion of $5 \mathrm{H} 1 \mathrm{mAb}$ up to $20 \mu \mathrm{g} / \mathrm{ml}$ during staining did not interfere with the binding of PD-1Ig. Inclusion of $5 \mathrm{H} 1 \mathrm{mAb}$, however, could inhibit the binding of B7-H1Ig to M99 T cell clone from $31 \%$ to $8 \%$ (Figure 2a), suggesting that $5 \mathrm{H} 1$ could partially block the binding of $\mathrm{B} 7-\mathrm{H} 1$ to a non-PD-1 receptor (16). Similar blocking function was also found using $2 \mathrm{H} 1 \mathrm{mAb}$ (data not shown).

FACS analysis using B7-H1 mAb showed that B7-H1 is not detectable on freshly isolated PBMC subsets with CD4, CD8, or CD45RO markers. However, stimulation by phytohemagglutinin (PHA), a T cell mitogen, rapidly upregulated expression of $\mathrm{B} 7-\mathrm{H} 1$ on $64.2 \%$ of $\mathrm{CD}^{+}$cells at 24 hours and $78.2 \%$ at 48 hours. Meanwhile, only $44.7 \%$ and $32.1 \%$ of $\mathrm{CD}^{+} \mathrm{T}$ cells expressed $\mathrm{B} 7-\mathrm{H} 1$ at 24 hours and 48 hours after PHA stimulation, respectively. High levels of B7-H1 (84.2\% at 24 hours and $62.3 \%$ at 48

\section{Figure 3}

B7- $\mathrm{H} 1 \mathrm{mAb}$ costimulates human $\mathrm{CD} 4^{+} \mathrm{T}$ cell proliferation. (a) Purified human $\mathrm{CD}^{+} \mathrm{T}$ cells were cultured with immobilized $10 \mu \mathrm{g} / \mathrm{ml}$ of control (ctl) Ab, B7-H1 mAb (2H1), PD-1 lg, and $2 \mu \mathrm{g} / \mathrm{ml}$ of CD28 $\mathrm{mAb}$ in the presence of precoated different dose of CD3 mAb. Cultures were pulsed with ${ }^{3} \mathrm{H}-\mathrm{TdR}$ for a final 16 hours, and the cells were harvested at 72 hours. (b) Dose-dependent costimulation of immobilized anti-B7-H1 mAb in the presence of suboptimal dose (30 $\mathrm{ng} / \mathrm{ml}$ ) of CD3 $\mathrm{mAb}$. Titration of $\mathrm{mAb}$ or fusion protein was started at $20 \mu \mathrm{g} / \mathrm{ml}$ of control Ab, B7-H1 mAb, PD-1lg, and $4 \mu \mathrm{g} / \mathrm{ml}$ of CD28 mAb. (c) Human CD4 ${ }^{+} \mathrm{T}$ cells were costimulated with 20 $\mu \mathrm{g} / \mathrm{ml}$ of soluble control (ctl) Ab, B7-H1 mAb (2H1), PD-1lg, and 2 $\mu \mathrm{g} / \mathrm{ml}$ of CD28 $\mathrm{mAb}$ as the same condition in a. (d) Blocking of B7-H1 mAb-mediated costimulation by soluble B7-H1lg. Soluble control $\mathrm{lg}, \mathrm{B} 7-1 \mathrm{lg}$, or $\mathrm{B} 7-\mathrm{H} 1 \mathrm{lg}(10 \mu \mathrm{g} / \mathrm{ml})$ was preincubated with immobilized control ( $\mathrm{ctl}) \mathrm{Ab}$ or $\mathrm{B} 7-\mathrm{H} 1 \mathrm{mAb}(2 \mathrm{H} 1)$ for 30 minutes before the addition of T cells. B7- $\mathrm{H} 1$ costimulation was assayed in the presence of suboptimal dose of CD3 mAb for 72 hours of culture. (e) FACS analysis of IL-2 receptor (CD25) expression in CD4 ${ }^{+} \mathrm{T}$ cells after $\mathrm{B} 7-\mathrm{H} 1 \mathrm{mAb}$ costimulation. (f) IL-10 secretion from $\mathrm{CD} 4^{+}$ $T$ cells in the presence of immobilized CD3 $\mathrm{mAb}(500 \mathrm{ng} / \mathrm{ml})$, and B7-H1 mAb $(10 \mu \mathrm{g} / \mathrm{ml})$, or CD28 mAb $(2 \mu \mathrm{g} / \mathrm{ml})$. hours) were also detected on $\mathrm{CD}^{2} 5 \mathrm{RO}^{+}$memory $\mathrm{T}$ cells (Figure $2 \mathrm{~b}$ ). We have also found that stimulation of $\mathrm{CD} 4^{+} \mathrm{T}$ cells with immobilized CD3 mAb in optimal doses rapidly upregulate the expression of $\mathrm{B} 7-\mathrm{H} 1$ within 24 hours, while suboptimal doses of $\mathrm{CD} 3 \mathrm{mAb}$ requires more than 48 hours to induce $\mathrm{B} 7-\mathrm{H} 1$ expression (data not shown). We conclude that $\mathrm{B} 7-\mathrm{H} 1$ is inducible on human $\mathrm{T}$ cells and is preferentially expressed on activated $\mathrm{CD} 4^{+} \mathrm{T}$ cells and $\mathrm{CD} 45 \mathrm{RO}^{+}$memory $\mathrm{T}$ cells.

To evaluate the function of $\mathrm{CD}^{+} \mathrm{T}$ cell-associated B7-H1, we stimulated purified human $\mathrm{CD}^{+} \mathrm{T}$ cells with suboptimal concentrations $(30 \mathrm{ng} / \mathrm{ml})$ of anti-CD3 $\mathrm{mAb}$ in combination with B7-H1 mAb. While anti-CD3 mAb alone induced an absent or weak $\mathrm{T}$ cell response, significant increases in $\mathrm{T}$ cell proliferation were observed by inclusion of B7-H1 mAb. This effect, however, was less potent than that of anti-CD28 mAb (Figure 3a). Costimulatory activity was also observed using immobilized human PD-1Ig fusion protein, suggesting an agonistic effect of B7-H1 mAb. The effect of the B7-H1 mAbs was dose dependent in a range of 2.5 to $10 \mu \mathrm{g} / \mathrm{ml}$ (Figure $3 \mathrm{~b}$ ). Immobilization of B7-H1 mAb was critical for the effect since B7-H1 mAb in soluble form in doses up to $20 \mu \mathrm{g} / \mathrm{ml}$ were ineffective (Figure 3c). TCR signaling was also required for proliferation, because $\mathrm{B} 7-\mathrm{H} 1 \mathrm{mAb}$ did not stimulate $\mathrm{T}$ cell proliferation in the absence of anti-CD3 $\mathrm{mAb}$ (Figure 3a). Inclusion of soluble B7-H1Ig, which competitively inhibits the interaction between $\mathrm{T}$ cell-associated $\mathrm{B} 7-\mathrm{H} 1$ and $\mathrm{B} 7-\mathrm{H} 1 \mathrm{mAb}$, significantly reduced the costimulatory effect of $\mathrm{B} 7-\mathrm{H} 1 \mathrm{mAb}$ on $\mathrm{T}$ cells. In contrast, soluble B7-1Ig or control Ig had no inhibitory effect (Figure $3 \mathrm{~d}$ ), confirming the specificity of the response.
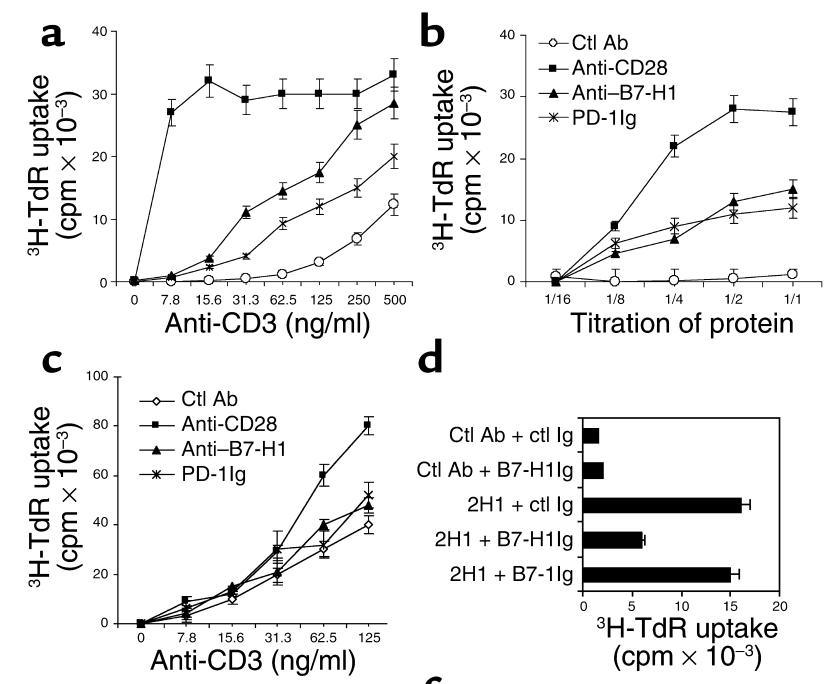

d
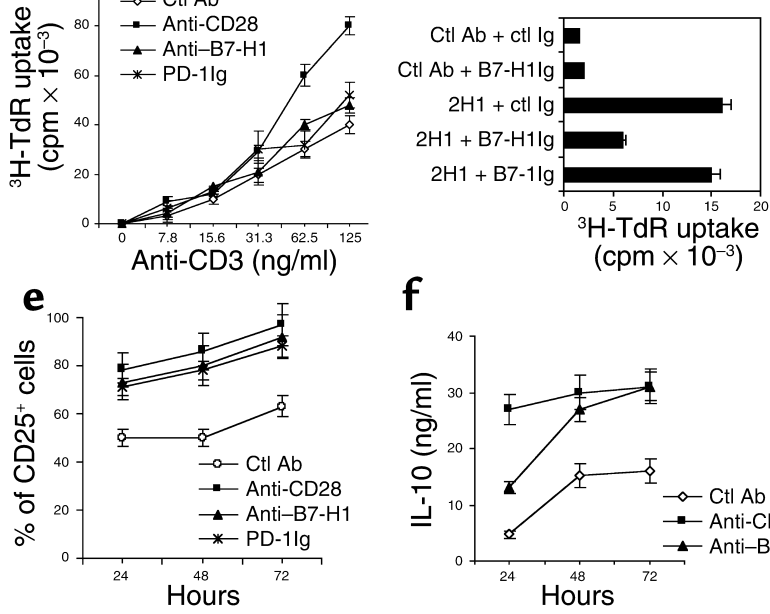

$f$

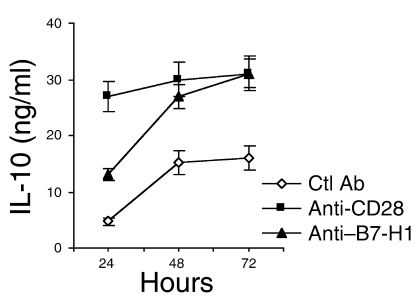



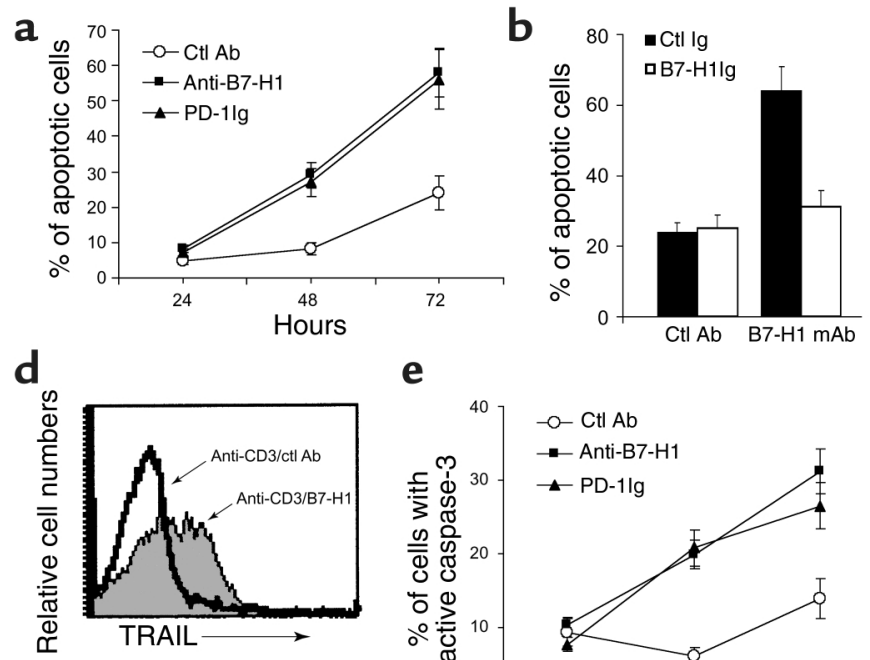

e

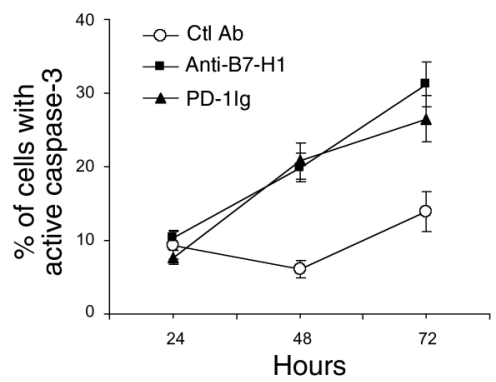

f

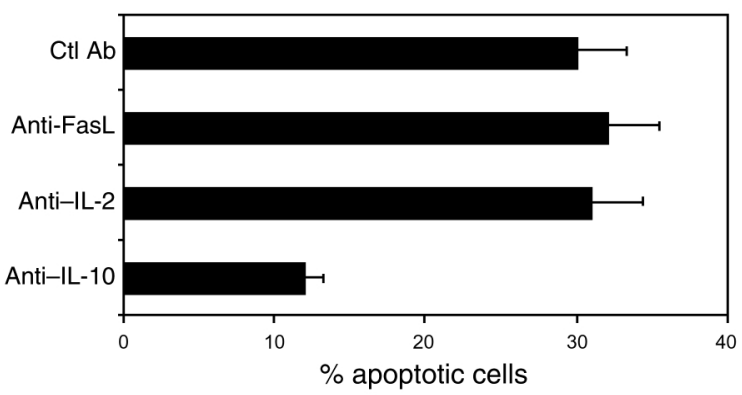

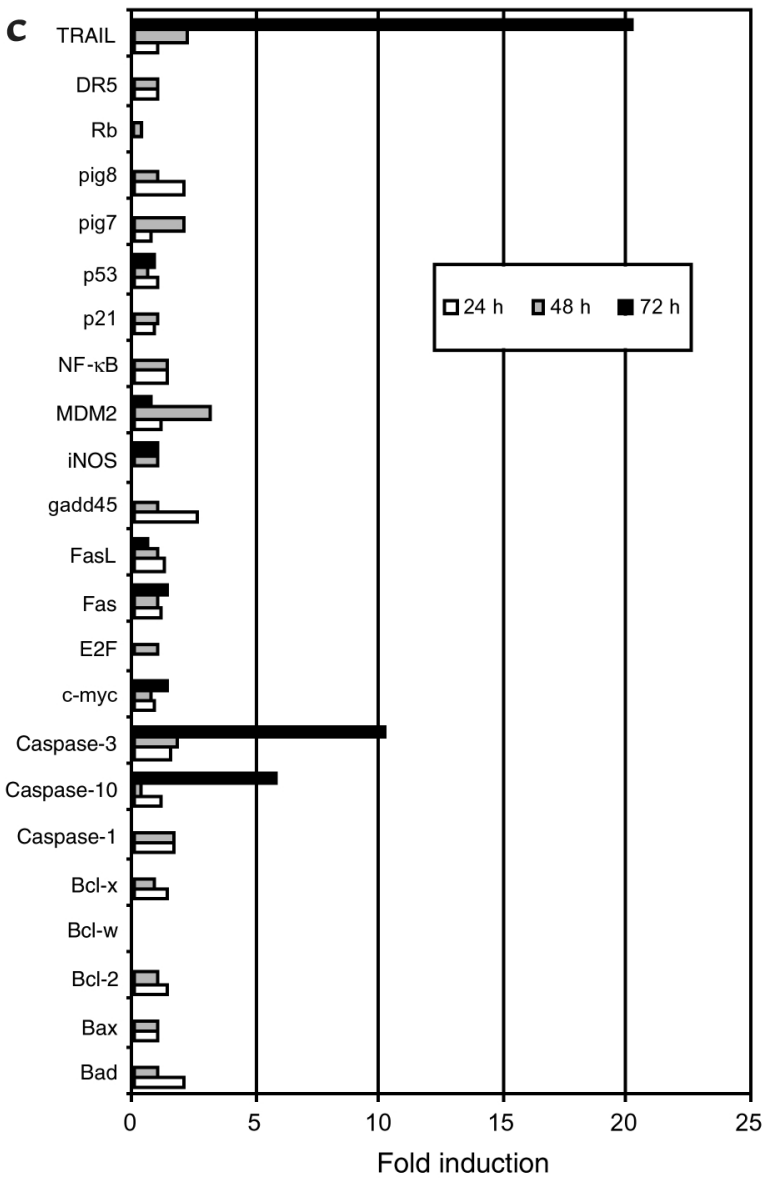

Figure 4

B7-H1 mAb promotes programmed cell death of activated CD4 ${ }^{+} \mathrm{T}$ cells. (a) Human $\mathrm{CD} 4^{+} \mathrm{T}$ cells were cultured with $10 \mu \mathrm{g} / \mathrm{ml}$ of immobilized control (ctl) Ab, B7-H1 mAb, PD-1 lg in the presence of precoated optimal dose $(500 \mathrm{ng} / \mathrm{ml})$ of CD3 mAb. The cells were analyzed by FACS to determine apoptotic cells (positive in $\mathrm{AV}$ and negative in PI staining). (b) Blocking of B7-H1 mAb-induced apoptosis by soluble $\mathrm{B} 7-\mathrm{H} 1 \mathrm{lg}$. Control Ig or $\mathrm{B} 7-\mathrm{H} 1 \mathrm{lg}$ at $10 \mu \mathrm{g} / \mathrm{ml}$ was preincubated with immobilized control $\mathrm{Ab}$ or $\mathrm{B} 7-\mathrm{H} 1 \mathrm{mAb}$ for 30 minutes before the addition of $\mathrm{T}$ cells. Percentages of apoptotic $\mathrm{CD} 4^{+} \mathrm{T}$ cells were shown at 72 hours of culture. (c) Expression of apoptotic genes by $\mathrm{B} 7-\mathrm{H} 1 \mathrm{mAb}$ costimulation. Purified human $\mathrm{CD} 4^{+} \mathrm{T}$ cells $\left(5 \times 10^{6}\right)$ were cultured with immobilized $\mathrm{B} 7-\mathrm{H} 1 \mathrm{mAb}$ or control mAb at $10 \mu \mathrm{g} / \mathrm{ml}$ in the presence of optimal dose of CD3 mAb. The mRNA levels of each gene from B7-H1 mAb-stimulated T cells were presented as the fold induction, relevant to that from control mAb-treated T cells. (d) FACS analysis of expression of TRAIL protein on CD4 ${ }^{+} \mathrm{T}$ cells 3 days after anti-CD3/B7-H1 $\mathrm{mAb}$ costimulation. (e) Purified human $\mathrm{CD} 4^{+} \mathrm{T}$ cells were stimulated in the presence of indicated $\mathrm{mAb}$ or fusion protein in immobilized form as indicated in the legend of $\mathbf{a}$ and the activated form of caspase- 3 at the indicated time point was stained by FAM-DEVD-FMK and subjected to FACS analysis. (f) Blocking of B7-H1 mAb-induced apoptosis of activated CD4+ $\mathrm{T}$ cells by anti-IL-10 neutralizing mAb. Purified human $\mathrm{CD} 4^{+} \mathrm{T}$ cells were stimulated with immobilized $\mathrm{CD} 3 \mathrm{mAb}$ and $\mathrm{B} 7-\mathrm{H} 1 \mathrm{mAb}$ for 72 hours, and the apoptotic cells were analyzed by $\mathrm{AV}$ and PI staining. Control $\mathrm{Ab}$ and $\mathrm{mAbs}$ to Fas ligand, IL-2, or IL-10 at $10 \mu \mathrm{g} / \mathrm{ml}$ was included at the beginning of the culture.

The costimulatory functions of $\mathrm{B} 7-\mathrm{H} 1 \mathrm{mAb}$ are very similar to the autoantibodies isolated from RA patients, which induced both phenotypic $\mathrm{T}$ cell changes and distinct patterns of cytokine secretion. Specifically, B7-H1 mAb induced high-levels of CD25 expression on $\mathrm{CD} 4^{+} \mathrm{T}$ cells, an effect similar to that using anti-CD3/CD28 mAb (Figure 3e). Additionally, anti-CD3/B7-H1 mAb costimulation led to increased secretion of IL-10 (Figure 3f). A small increase of IFN- $\gamma$ secretion was also observed in culture supernatant, while IL-2 and IL-4 were not detected (data not shown). Taken together, our results suggest a reverse-signaling function of $\mathrm{B} 7-\mathrm{H} 1$ for $\mathrm{CD} 4^{+}$ $\mathrm{T}$ cell costimulation.
Promoting apoptosis of activated $\mathrm{CD} 4^{+}$T cells by B7-H1 $\mathrm{mAb}$. We have shown that one role of $\mathrm{B} 7-\mathrm{H} 1 \mathrm{mAb}$ is to promote proliferation of $\mathrm{CD} 4^{+} \mathrm{T}$ cells. This suggests that B7-H1 autoantibodies in RA patients may contribute to the persistent activation of newly recruited $T$ cells when they encounter self antigens. In RA patients, however, many $\mathrm{CD} 4^{+} \mathrm{T}$ cells are already mature/activated. The effect of B7-H1 triggering by Ab's on activated T cells may be different from those observed on primary $T$ cells. To examine the effect of $\mathrm{B} 7-\mathrm{H} 1 \mathrm{mAb}$ on activated $\mathrm{CD} 4^{+}$ $T$ cells, we employed an in vitro culture system in which optimal doses of anti-CD3 mAb can drive $\mathrm{T}$ cell proliferation without additional costimulation. In this setting, B7-H1 mAb significantly increased apoptosis of 
$\mathrm{CD} 4^{+} \mathrm{T}$ cells, as determined by double staining of PI and $\mathrm{AV}$ (Figure 4a). The cell death induced by B7-H1 mAb was completely abrogated by preincubation of the $\mathrm{mAb}$ with B7-H1Ig, but not with control Ig (Figure 4b). Similarly, immobilized PD-1Ig also increased apoptosis of activated $T$ cells. Neither soluble nor immobilized $\mathrm{mAb}$ to B7-H1 or PD-1Ig alone had an effect (data not shown). In a different setting, $\mathrm{CD}^{+} \mathrm{T}$ cells were preactivated by optimal doses of anti-CD $3 \mathrm{mAb}$ for 48 hours, in which all $\mathrm{CD}^{+} \mathrm{T}$ cells express high levels of B7-H1, and further stimulated with B7-H1 mAb. Similarly, preactivated $T$ cells also had increased apoptosis after exposure to a coligation of immobilized anti-CD3/B7-H1 $\mathrm{mAb}$, but not to ligation of $\mathrm{B} 7-\mathrm{H} 1 \mathrm{mAb}$ alone (data not shown). Our results suggest that $\mathrm{B} 7-\mathrm{H} 1 \mathrm{mAb}$ in the presence of strong TCR signaling promotes apoptosis of activated $\mathrm{CD} 4^{+} \mathrm{T}$ cells.

To define the mechanism of the apoptotic effect, we used DNA arrays for expression analysis of apoptosisrelated genes stimulated by $\mathrm{B} 7-\mathrm{H} 1 \mathrm{mAb}$. Up to 72 hours after ligation with anti-CD3/B7-H1 mAb, mRNA from $\mathrm{CD} 4^{+} \mathrm{T}$ cells was extracted and hybridized to a DNA array membrane. In three separate experiments, transcription of caspase- 10 and caspase- 3 genes was reproducibly increased. TRAIL was also upregulated (Figure 4c). Enhanced gene expression was also confirmed by protein analysis. Specifically, elevated TRAIL was found in anti-CD3/B7-H1 mAb-stimulated T cells by staining with anti-TRAIL Ab in FACS analysis (Figure $4 d$ ). Significant increases of active caspase-3 were also detected at 48 and 72 hours after stimulation (Figure 4e). Neither B7-H1 mAb nor anti-CD3 (at suboptimal doses) alone stimulated these changes. Anti-CD3 at high dose $(1 \mu \mathrm{g} / \mathrm{ml})$ could induce the activation of caspase 3 but not the expression of TRAIL in activated $\mathrm{CD}^{+} \mathrm{T}$ cells (data not shown). These observations emphasize dependence of a TCR signal in the effect of B7-H1 mAb. Our results suggest that B7-H1 mAb upregulates caspases and TRAIL on T cells, which may facilitate activation-induced death of $\mathrm{CD} 4^{+} \mathrm{T}$ cells.

IL-10 is a potent immunosuppressive cytokine that stimulates $\mathrm{Th} 2 \mathrm{CD} 4^{+} \mathrm{T}$ cell responses and enhances the apoptosis of activated human T cells (20-23). B7-H1 $\mathrm{mAb}$ stimulated secretion of IL-10 from activated $\mathrm{CD}^{+} \mathrm{T}$ cells (Figure $3 \mathrm{f}$ ), providing presumptive evidence that IL-10 might play a role in the increased apoptosis induced by B7-H1 mAb. To test this hypothesis, we examined whether neutralization of IL-10 in anti-CD3/B7-H1 mAb inhibited apoptosis. As shown in Figure 4f, inclusion of anti-IL-10 mAb significantly reduced the amount of apoptosis induced by anti$\mathrm{CD} 3 / \mathrm{B} 7-\mathrm{H} 1 \mathrm{mAb}$ at 72 hours. In contrast, neutralizing Ab's against Fas ligand and IL-2 had no effect. Our results suggest that IL-10 facilitates, at least in part, the induction of apoptosis by B7-H1 mAb ligation.

\section{Discussion}

Autoantibodies to B7-H1 are found in the sera of a significant portion of the RA patients, and the existence of the autoantibodies is correlated with active status of the disease. This finding suggests a role of B7-H1 autoantibodies in the progression of RA. Further studies indicate that human $\mathrm{CD}^{+} \mathrm{T}$ cells preferentially express $\mathrm{B} 7-\mathrm{H} 1$ and engagement of $\mathrm{T}$ cell-associated $\mathrm{B} 7-\mathrm{H} 1$ by Ab costimulate activation, proliferation, cytokine secretion, and programmed cell death. Our results thus support a role of T cell-associated B7-H1 in reverse signaling of $\mathrm{CD}^{+} \mathrm{T}$ cells, and increased B7-H1 autoantibodies may play a role in aberrant activation of $\mathrm{T}$ cells in RA and possibly other systemic autoimmune diseases.

Correlation between the existence of elevated autoantibodies in RA patients and active disease provides an important clue to consider regarding the potential role of B7-H1 autoantibodies in the progression of diseases. It is unknown, however, whether or not B7-H1 autoantibodies are also quantitatively correlated with active diseases due to the semiquantitative nature of ELISA and subjective diagnostic standard for active diseases. Our in vitro studies, however, suggest an important contribution of B7-H1 autoantibodies in aberrant T cell responses, which is often observed in RA patients, by costimulating the resting $T$ cells and inducing apoptosis of preactivated $T$ cells. It is attempting to speculate that $\mathrm{CD}^{+} \mathrm{T}$ cells in RA patients will have a higher turnover rate and shorter life of $\mathrm{T}$ cells in the presence of B7-H1 autoantibodies. One should keep in mind that our results could represent a gross underestimate of the importance of B7-H1 autoantibodies in the pathogenesis of RA. Specifically, nearly all of the therapeutic agents (e.g., methotrexate) employed have regulatory effects on the immune system and $\mathrm{T}$ cell biology, making correlation of clinical markers of disease and B7-H1 expression very difficult (24). Importantly, definition of the effects of individual agents on $\mathrm{B} 7-\mathrm{H} 1$ expression may facilitate correlation of autoantibody detection with both diagnosis and disease activity.

Although our results support that engagement of $\mathrm{T}$ cell-associated B7-H1 transmits functional signaling, the nature of this signaling is unknown. The cytoplasmic domain of B7-H1 does not contain obvious structural elements that are directly relevant to signaling for cell activation or death $(25,26)$. Therefore, adapter proteins might play a role in transmitting $\mathrm{B} 7-\mathrm{H} 1$ signal to $\mathrm{T}$ cells. It is possible that multiple signaling pathways might be involved, since B7-H1 signaling leads to diverse outcomes including costimulation of $\mathrm{T}$ cell growth, secretion of IL-10, upregulation of caspases, and TRAIL leading to increased apoptosis of activated $T$ cells. In addition to autoantibodies, binding of B7-H1 by PD-1 receptor may also play a role in the $\mathrm{B} 7-\mathrm{H} 1$ signaling. PD-1 is a CTLA-4-like molecule expressed on activated $\mathrm{T}$ cells and has been implicated as a receptor for $\mathrm{B} 7-\mathrm{H} 1$ (15). PD-1-deficient mice spontaneously develop systemic lupus-like autoimmune diseases characterized by immune complex deposits in the renal parenchyma of aged $\mathrm{B} 6$ mice (27). The in vitro effects of B7-H1 autoantibody ligation were analogous to those observed with immobilized PD-1I g (Figure 3), suggesting a possible 
role of PD-1 as a ligand to trigger $\mathrm{T}$ cell-associated $\mathrm{B} 7-\mathrm{H} 1$ in aberrant $\mathrm{CD} 4^{+} \mathrm{T}$ cell activation in RA patients. Further studies are needed to clarify these issues.

Our results reveal that activated T cells could simultaneously express B7-H1, PD-1, and the putative second B7-H1 receptor. Therefore, B7-H1 Ab's can potentially affect the interactions among these molecules. While our results strongly support that B7-H1 autoantibodies directly deliver an activation signal to $T$ cells by crosslinking B7-H1, it is also possible that B7-H1 Ab's may block or "sequestrate" B7-H1 from interacting with $\mathrm{PD}-1$, leading to a decreased negative signaling for $\mathrm{T}$ cell response. Several lines of evidence, however, do not support this hypothesis in our system. We demonstrate that only immobilized B7-H1 Ab's could induce reverse costimulation while soluble Ab's did not (Figure 3c). This result emphasizes the importance of cross-linking rather than neutralizing Ab's in the activation of T cells. Furthermore, our $5 \mathrm{H} 1 \mathrm{mAb}$ could not block the interaction between B7-H1 and PD-1, whereas it can partially inhibit binding of B7-H1 to a non-PD-1 receptor on M99 T cells (Figure 2a). This result suggests that blocking or "sequestration" of B7-H1 by Ab's in our experimental condition would still allow B7-H1 to interact with PD-1. Consistent with these findings, reverse costimulation by B7-H1 autoantibodies could not be blocked by PD-1Ig (Figure 1b), a result similar to our previous finding that $\mathrm{PD}-1 \mathrm{Ig}$ also did not block the effect of anti-CD3 $\mathrm{mAb}$ in the stimulation of $\mathrm{T}$ cell proliferation and cytokine production (16). Taken together, our results suggest that PD- 1 is not involved in the suppression of $\mathrm{T}$ cell responses in our systems.

The prevalence of autoantibodies to B7-H1 in the sera of RA patients raised the question as to why tolerance to B7-H1 is broken. Actually, we did not detect any $\mathrm{B} 7-\mathrm{H} 1$ expression on the freshly isolated $\mathrm{T}$ cells from ten RA patients (unpublished observation). This may be caused by transient nature of B7-H1 expression and by the anti-inflammation treatment of these patients. Previously, we have reported that the mRNA of B7-H1 can be detected in various organs, including heart, lung, liver, placenta, and spleen in healthy individuals. However, immunohistochemistry analysis using B7-H1 mAb demonstrates no evidence of protein expression, except macrophage-derived cells, including Kupffer cells in liver and monocytes in blood (16). Expression of B7-H1, however, can be induced in cells such as activated $\mathrm{T}$ cells $(14,18)$. It is thus possible that in autoimmune diseases, inflammatory tissues and cells may lead to ectopic expression of B7-H1, which might serve as an antigen source for elicitation of autoantibodies. Recently we have found similar increases of B7-H1 autoantibodies in patients with systemic lupus erythematosus and autoimmune inner ear disease (unpublished data). Defining the roles of B7-H1 and gaining a better understanding of the molecular pathways elicited after B7-H1 ligation will facilitate the development of novel therapies for the treatment of autoimmune disease.

\section{Acknowledgments}

This study was supported by the Mayo Foundation. We thank Jorg J. Goronzy and K. Tamada for helpful discussion, Stephen S. Cha for statistical analysis, Jane Jaquith and Lucinda Hinkley for their work as study coordinators, and Kathy Jensen and Julie Lau for editing the manuscript and graphs.

1. Palmer, D.G. 1995. The anatomy of the rheumatoid lesion. Br. Med. Bull. 51:286-295.

2. Salmon, M., and Gaston, J.S. 1995. The role of T-lymphocytes in rheumatoid arthritis. Br. Med. Bull. 51:332-345.

3. Hemler, M.E., Glass, D., Coblyn, J.S., and Jacobson, J.G. 1986.Very late activation antigens on rheumatoid synovial fluid T lymphocytes. Association with stages of T cell activation. J. Clin. Invest. 78:696-702.

4. Trapp, B.D., et al. 1998. Axonal transection in the lesions of multiple sclerosis. N. Engl. J. Med. 338:278-285.

5. Torres, B.A., and Johnson, H.M. 1998. Modulation of disease by superantigens. Curr. Opin. Immunol. 10:465-470.

6. Koetz, K., et al. 2000. T cell homeostasis in patients with rheumatoid arthritis. Proc. Natl. Acad. Sci. USA. 97:9203-9208.

7. Linsley, P.S., and Ledbetter, J.A. 1993. The role of the CD28 receptor during T cell responses to antigen. Annu. Rev. Immunol. 11:191-212.

8. Chambers, C.A., and Allison, J.P. 1997. Co-stimulation in T cell responses. Curr. Opin. Immunol. 9:369-404.

9. Ye, Z., et al. 2002. Gene therapy for cancer using single-chain Fv fragments specific for 4-1BB. Nat. Med. 8:343-348.

10. Chen, L. 2002. Antibody gene therapy: old wine in a new bottle. Nat. Med. 8:333-334.

11. Hazenbos, W.L.W., et al. 1996. Impaired IgG-dependent anaphylaxis and Arthus reaction in Fc gamma RIII (CD16) deficient mice. Immunity. 5:181-188.

12. Ioan-Facsinay, A., et al. 2002. Fc $\gamma R I$ (CD64) contributes substantially to severity of arthritis, hypersensitivity responses, and protection from bacterial infection. Immunity. 16:391-402.

13. Matsui, T., et al. 1999. Autoantibodies to T cell costimulatory molecules in systemic autoimmune diseases. J. Immunol. 162:4328-4335.

14. Dong, H., Zhu, G., Tamada, K., and Chen, L. 1999. B7-H1, a third member of the B7 family, co-stimulates T-cell proliferation and interleukin-10 secretion. Nat. Med. 5:1365-1369.

15. Freeman, G.J., et al. 2000. Engagement of the PD-1 immunoinhibitory receptor by a novel B7 family member leads to negative regulation of lymphocyte activation. J. Exp. Med. 192:1027-1034.

16. Dong, H., et al. 2002. Tumor-associated B7-H1 promotes T-cell apoptosis: a potential mechanism of immune evasion. Nat. Med. 8:793-800.

17. Jeannin, P., et al. 1997. CD86 (B7-2) on human B cells. A functional role in proliferation and selective differentiation into IgE- and IgG4-producing cells. J. Biol. Chem. 272:15613-15619.

18. Tamura, H., et al. 2001. B7-H1 costimulation preferentially enhances CD28-independent T-helper cell function. Blood. 97:1809-1816.

19. Felson, D.T., et al. 1995. American College of Rheumatology. Preliminary definition of improvement in rheumatoid arthritis. Arthritis Rheum. 38:727-735.

20. Georgescu, L., Vakkalanka, R.K., Elkon, K.B., and Crow, M.K. 1997. Interleukin-10 promotes activation-induced cell death of SLE lymphocytes mediated by Fas ligand. J. Clin. Invest. 100:2622-2633.

21. Saito, I., et al. 1999. Fas ligand-mediated exocrinopathy resembling Sjogren's syndrome in mice transgenic for IL-10. J. Immunol. 162:2488-2494.

22. Mignon-Godefroy, K., Rott, O., Brazillet, M.P., and Charreire, J. 1995. Curative and protective effects of IL-10 in experimental autoimmune thyroiditis (EAT). Evidence for IL-10-enhanced cell death in EAT. J. Immunol. 154:6634-6643.

23. Clerici, M., et al. 1994. Type 1/type 2 cytokine modulation of T-cell programmed cell death as a model for human immunodeficiency virus pathogenesis. Proc. Natl. Acad. Sci. USA. 91:11811-11815.

24. Genestier, L., et al. 1998. Immunosuppressive properties of methotrexate: apoptosis and clonal deletion of activated peripheral T cells. J. Clin. Invest. 102:322-328.

25. Zhang, J., Cado, D., Chen, A., Kabra, N.H., and Winoto, A. 1998. Fasmediated apoptosis and activation-induced T-cell proliferation are defective in mice lacking FADD/Mort1. Nature. 392:296-300.

26. Siegel, R.M., Chan, F.K., Chun, H.J., and Lenardo, M.J. 2000. The multifaceted role of Fas signaling in immune cell homeostasis and autoimmunity. Nat. Immunol. 1:469-474.

27. Nishimura, H., Nose, M., Hiai, H., Minato, N., and Honjo, T. 1999. Development of lupus-like autoimmune diseases by disruption of the PD-1 gene encoding an ITIM motif-carrying immunoreceptor. Immunity. 11:141-151. 